\title{
Uridine-induced hypothermia in mice and rats in relation to plasma and tissue levels of uridine and its metabolites
}

\section{G. J. Peters, C. J. van Groeningen, E. J. Laurensse, J. Lankelma, A. Leyva, and H. M. Pinedo}

Department of Oncology, Free University Hospital, P. O. Box 7057, 1007 MB Amsterdam, The Netherlands

Cancer Chemother Pharmacol (1987) 20:101-108

On page 106, lines 16-17 should read: It might also be possible that the uridine-induced hyperthermia (and not, as originally printed, hypothermia) is a shock-like effect due to a sudden load of salts. 